Etikonomi

Volume 15 (2), October 2016

P-ISSN: 1412-8969; E-ISSN: 2461-0771

Page 97 - 110

\title{
THE TOTAL PERFORMANCE SCORECARD: CASE AT UIN SYARIF HIDAYATULLAH JAKARTA
}

\author{
Suhendra \\ UIN Syarif Hidayatullah Jakarta \\ suhendra.feb@uinjkt.ac.id
}

\begin{abstract}
.
This study aims to identify and analyse Total Human Resources Champions Management in relation to the Total Performance Scorecard. This study uses primary data by distributing questionnaires to the respondents, the 30 heads of department, 60 lecturers, 30 administrative staffs and 60 students of UIN Syarif Hidayatullah Jakarta. Partial Least Square (PLS) had been used. Results from this study showed that all dimensions of Total Human Resources Champions Management (Human Resources Strategic Management, Infrastructure Management Firm, Management Employee Contribution, Management of Transformation and Changes, Spiritual and Campaign Management, Talent Management) affected on Total Human Resources Champions Management, furthermore, Total Human Resources Champions Management has a significant positive effect on the Total Performance Scorecard course at UIN Syarif Hidayatullah Jakarta.
\end{abstract}

Keywords: total human resources champions management; total performance scorecard

\begin{abstract}
Abstrak.
Penelitian ini bertujuan untuk mengidentifikasi dan menganalisis Total Human Resources Champions Management dalam kaitannya dengan Total Performance Scorecard. Penelitian ini menggunakan data primer dengan menyebarkan kuesioner kepada responden, 30 kepala program studi, 60 dosen, 30 staf administrasi dan 60 mahasiswa dari UIN Syarif Hidayatullah Jakarta. Partial Least Square (PLS) telah digunakan dalam analisis ini. Hasil dari penelitian ini menunjukkan bahwa semua dimensi Total Human Resources Champions Management (Human Resourches Manajemen Strategis, Badan Pengelolaan Infrastruktur, Manajemen Kontribusi Karyawan, Manajemen Transformasi dan Perubahan, Spiritual dan Manajemen Kampanye, Talent Management) berpengaruh terhadap Total Human Resources Champions Management, selanjutnya, Total Human Resources Champions Management memiliki efek positif yang signifikan pada Total Performance Scorecard di UIN Syarif Hidayatullah Jakarta.
\end{abstract}

Kata Kunci: Total Human Resources Champions Management, Total Performance Score Card

First Draft: May 15, 2016; Revised: August 10, 2016; Approved: September 5, 2016. 
The Total Performance Scorecard at UIN Syarif Hidayatullah Jakarta

Suhendra

\section{INTRODUCTION}

The quality improvement of consumer is very important for the university survival under dynamic conditions. In addition, the policy regarding the quality management strategy of university can be a mirror for outsiders, especially students and prospective students that the quality of education is the main priority of the university.

In the international education context, the Global Alliance for Transnational Education (GATE) defines quality as meeting or fulfilling requirements, often referred to as fitness for purpose (GATE, 1998). In relation with the fulfilment of the minimum standards approach, the standard is defined as a level or grade of the goodness of something, and in an education context may be defined as an explicit level of academic attainment. It is clear that the standard functions among others as a means of criteria measurements by which quality may be judged (GATE, 1998). Meanwhile, according to Harvey and Green (1993) quality is defined as a relative concept that changed with the context and mean different things to different people. This is because in fact that the same person might apply different concepts at the others. Theoretically, there are two approaches that can be used to understand the meaning of quality. First, the quality reflects a characteristic possessed. In this viewpoint, something that is seen as something of quality excellence / quality valuable and did not have what is called evaluative sense (Margetson, 1994).

It can be concluded that the quality of higher education was defined as reaching the goal of a university that generally include a "tri dharma" concept and the measurement is carried out with exceptional approach where according to Porter (1994) has three variations i.e. 1) the quality as something distinctive, 2) quality as something that excellence, and 3) quality as something that meet the minimum or conformance standards. Conditions such as the above should be anticipated earlier by the organization, both business and the public. Communities will increasingly critical pick colleges that have good quality. It sort of becomes a reference for an organization to further improve productivity and the quality of education so that the destination organization that has launched can be achieved. 
Human resources are a potential source of competitive advantage for its competence in the form of intellectuality, character, skills, personal character, as well as intellectual and cognitive processes, cannot be imitated by other companies. No doubt within the scope of certain industries that lucrative and competitive will be variance with hijacking the human resources to stimulate the company's competitive advantage. It is very important contribution of human resources as one factor supporting the success of the organization so recognized by the top management of the organization. So organizations are required to undertake continuous development of the quantity and quality of the "stock" of their knowledge through training to HR or stimulate its human resources in order to "learning by doing" in a spirit embodied in a "learning organization".

The strengthening of an institution to be able to compete is not separated from the support of human resources, because in an organization, a variety of resources, both human resources and other resources are integrated in achieving organizational objectives. Among the resources the organization's human resources initiative, mobilizing and determining the activities Tiu integration and management activities in this organization is determined by competence, motivation and effectiveness of the people in the organization. Therefore, the management of human resources in an organization is very important, and in human resource management efforts are expected to acquire and produce employees who have high performance.

Charges against new role function HR in line with the message delivered by Dave Ulrich a Professor of Corporate Development from the University of Michigan: In the field of Human Resources, death rites have been proclaimed, eulogies written and funerals prepared for the demise of the HR Function. But these eulogies are premature. HR as we know it (with images of policy police, regulators, administrative guardian) has passed, and the rise of the new HR is well underway. According to Ulrich, there are four roles of human resources in order to build a strong organization, flexible, adaptive and competitive organization that led to the winner. The fourth roles of HR is the strategic management of human resources, management of transformation and change, management of firm infrastructure and management of employee contribution. Each role has its own 
The Total Performance Scorecard at UIN Syarif Hidayatullah Jakarta

Suhendra

specifications. However, each of these roles is always in contact and complementary. Total Human Resources Management Champions is a process management of HR activities spiritual superior global perspective to achieve citizen satisfaction with stakeholders.

Changing in the institutional form of six-Institut Agama Islam Negeri (UIN Syarif Hidayatullah Jakarta) requires attention to institutional capacity surrounding the managerial capability, financial, inter-agency cooperation, human resources, and others. The capacity of institutions at the State Islamic University is still weaker than the institutions of state higher education in general. From 2002 to 2014, UIN Syarif Hidayatullah Jakarta faced with a tough challenge, namely, how to produce quality output and must also be able to adapt to the dynamic changes in line with developments in science, technology, politics, economy and culture.

Challenging and an opportunity must be balanced with the quality and quantity of human resources management in the environment of the State Islamic University. As one measure of the competence of human capital, education level conditions lecturer at State Islamic University is still not yet high, or in other words do not meet the criteria established in Law No. 14 of 2005 on Teachers and Lecturers, namely for teaching in the undergraduate program lecturers should be minimal degree Bachelor Strata two, and for the graduate program the lecturer must hold a doctorate.

Table 1.Total of Lecturers and Its Education Level

\begin{tabular}{rrrrrrrrc}
\hline \multirow{2}{*}{ NO } & NAMA & S3 & S2 & S1 & SP - & PRO \\
& PERGURUAN TINGGI & \multirow{2}{*}{ D4 } & Jumlah \\
& & & & FESI & \\
\hline 1 & UIN Syarif Hidayatullah & 119 & 581 & 123 & 6 & 1 & 830 \\
\hline
\end{tabular}

Source: http://evaluasi.dikti.go.id

Various problems related to organizational performance, organizationally State Islamic University has been working to improve institutional capacity building institution, which was originally from IAIN to UIN by developing philosophy basis of the incorporation effort duality paradigm. Various concepts are 
demanding their sixth UIN providing education to the "wider mandate" not only education religious sciences alone, but also teaching general sciences.

One effort that can be done to improve the performance of the integrated by Rampersad is the application of the Total Performance Scorecard (TPS). TPS is a development of the Balanced Scorecard (BSC). It covers the whole unity of the organization's mission and vision, key roles, core values, critical success factors, objectives, performance measures, targets and improvement actions. Finally it is a result of the improvement, development and continuous mutual learning.

\section{METHOD}

This study is economics research, especially on the field of management, which focuses on areas of strategic human resource management. Object and scope of this study includes the Total Human Resources Champions Management and Total Performance Scorecard UIN Syarif Hidayatullah Jakarta. This study used a descriptive-verification. The author uses descriptive research method-verification because it provides a concrete and accurate description of the facts, properties and influence between the variables studied. By using this method will be described in detail and clearly the behaviour of each variables studied and therefore the research methods that will be used is called the explanatory research (explanatory survey).

The next step is testing measurement model. The measurement model is basically the validity and reliability whose goal is to measure the relationship between the indicator constructed, in other words, this model illustrates how big the indicators in the model to explain the constructs or latent variables. The analysis of this model is also called confirmatory factor analysis (CFA). In this study, the measurement model test conducted on the manifest variable or variables were observed (observe variable) that form factors or latent variables (un-observe variable) used in the study.

The following research model based on the concept in the literature as figure 1 below: 
The Total Performance Scorecard at UIN Syarif Hidayatullah Jakarta

Suhendra

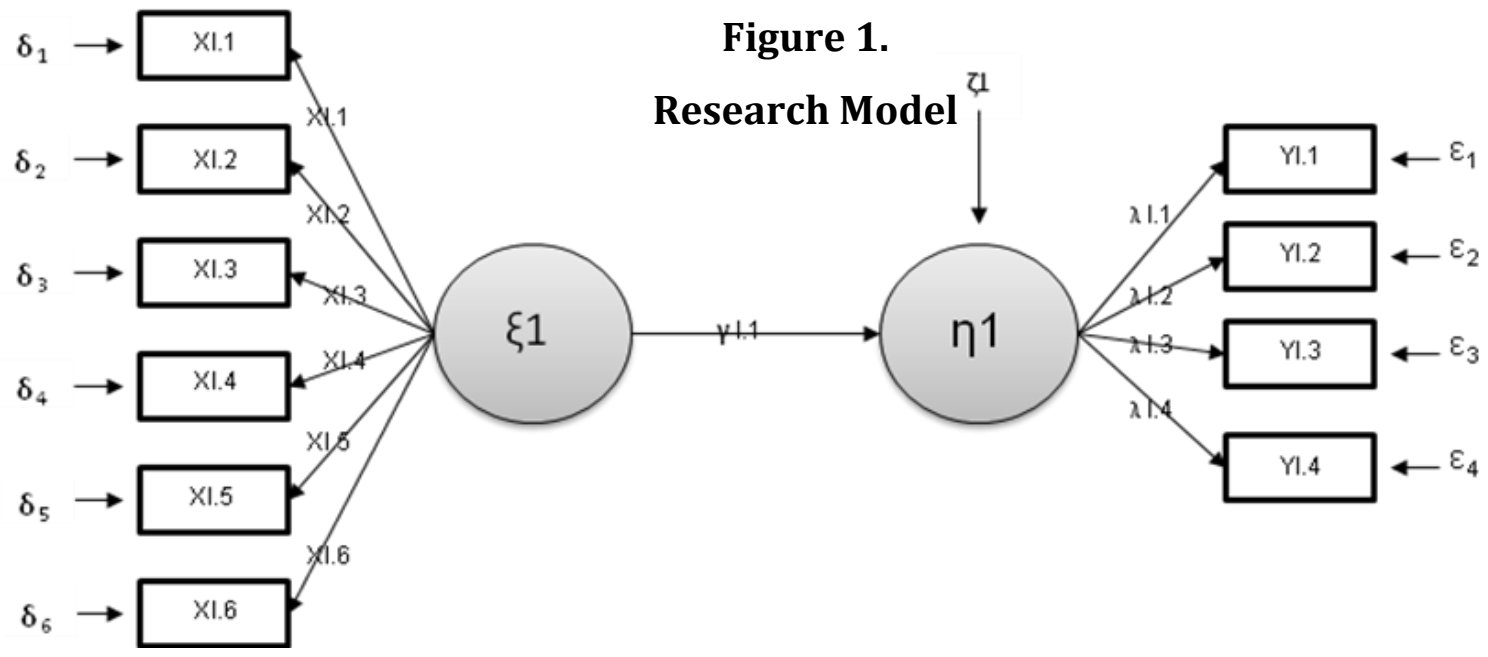

\section{DISCUSSION}

Figure 2shows based on the obtained information related to the coefficient of influence between latent variables and factor loading value of each latent variable. Rated loading factor is generally greater than 0.5 or can be seen from the P-value is below the 0.05 alpha so that a dimension or indicators significantly influence the latent variables.

Figure 2.

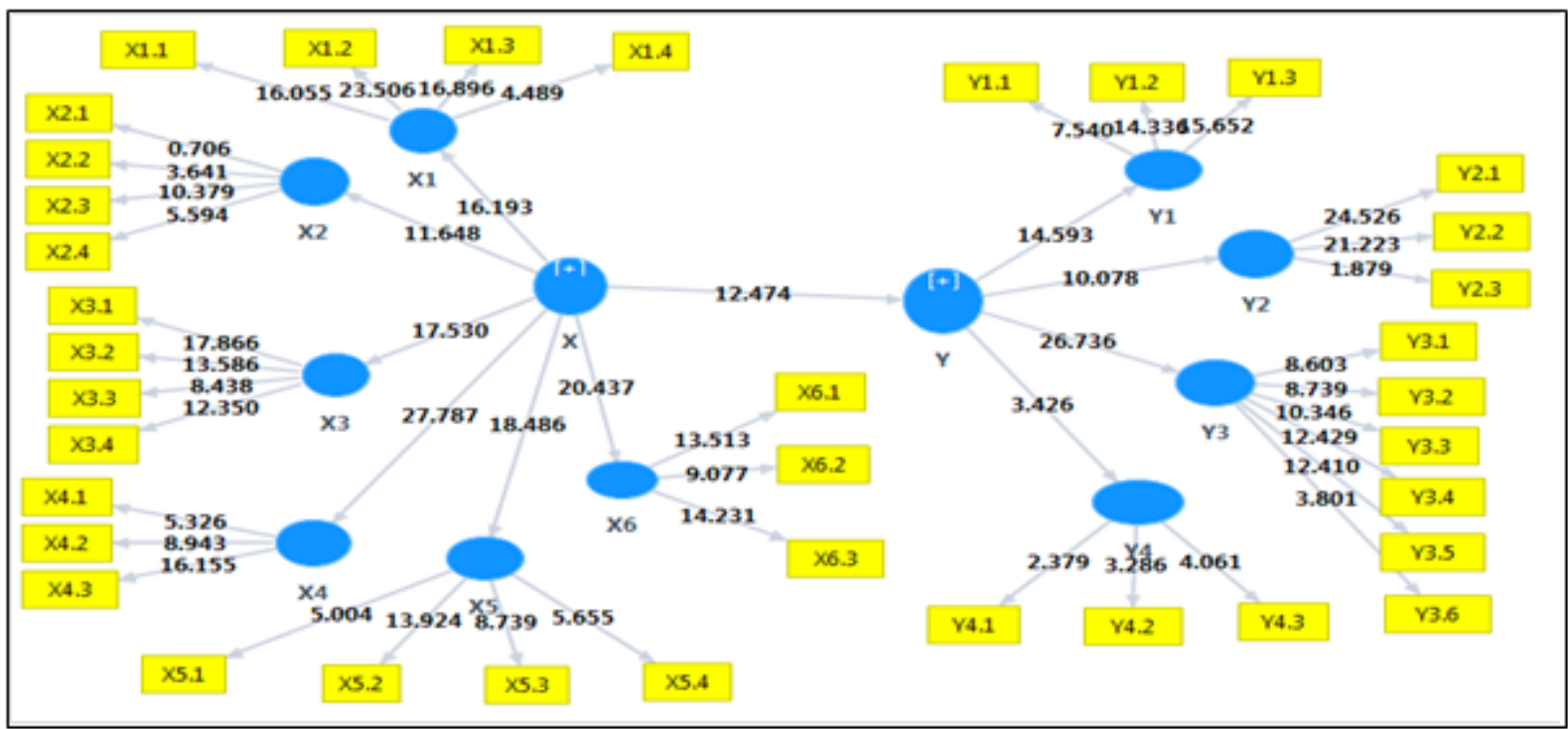

If viewed from latent variables respective with dimensions it is known that for the variable Total Human Resources Management Champion dimensions (Human Resources Strategic Management, Infrastructure Management Firm, 
Management Employee Contribution, Management of Transformation and Changes Spiritual and Campaign Management, Talent Management) All dimensions capable affects to Champion Total Human Resources Management because it has a high value of loading factor and $n$ p-value already meet the standards. Thus the total dimensions of Human Resources Management Champion (Human Resources Strategic Management, Infrastructure Management Firm, Management Employee Contribution, Management of Transformation and Changes, Spiritual and Campaign Management, Talent Management) affect to the Total Human Resources Management Champion course at UIN Syarif Hidayatullah.

Strategic Management Human Resources dimension i.e. organizational culture indicators: structure, people and human resources systems, four indicators are able to influence the Strategic Management of Human Resources because it has a high value of loading factor and $n$ p-value already meet the standards. Thus :, organizational culture indicators : structure, people and human resources systems affect the Strategic Management of Human Resources course at UIN Syarif Hidayatullah.

Management Firm dimension is indicators autonomous infrastructure, communications, technology and relationships among departments. Autonomous indicators have not been able to influence Infrastructure Management Firm because it has a low loading factor value and $n \mathrm{p}$-value that does not meet the standards. Autonomous and thus do not affect the Firm Infrastructure Management course at UIN Syarif Hidayatullah. Meanwhile, other indicators such as communications, technology and relationships between departments are able to influence Infrastructure Management Firm because it has a high value of loading factor and $\mathrm{n}$ p-value already meet the standards. Thus indicators of communication, technology and the relationship between departments affect the Firm Infrastructure Management course at UIN Syarif Hidayatullah.

Management Employee Contribution dimension to the indicators that skill in work, motivation and high performance, able to socialize with the work environment, have creative ideas to solve problems in the job. All indicators capable of effecting Management Employee Contribution for having a high 
The Total Performance Scorecard at UIN Syarif Hidayatullah Jakarta

Suhendra

loading factor value and $\mathrm{n} p$-value already meet the standards. Thus the indicator skill in work, motivation and high performance, able to socialize with the work environment, have creative ideas to solve problems in the work affect the Management Employee Contribution course at UIN Syarif Hidayatullah.

Management Transformation dimensionand change with indicators such as drivers of change, facilitator of change, system designers to change. All indicators are able to influence and change Management Transformation because it has a high value of loading factor and $n \mathrm{p}$-value already meet the standards. Thus indicators Drivers of change, facilitator of change, system designers for changes affect the Management Transformation and change course at UIN Syarif Hidayatullah.

Spiritual Management Promotionsdimension with indicators ofQuality of Work Life, Citizenship organization, Quality and Business ethics serve. All indicators were able to influence the Spiritual Management Promotions because it has a high value of loading factor and $\mathrm{n} p$-value already meet the standards. Thus indicators of Quality of Work Life, Citizenship organization, Service Quality and Business Ethics influence the Spiritual Management Promotion s course at UIN Syarif Hidayatullah.

Talent Management dimension with indicators such as recruitment and selection, maintaining and developing. All indicators capable of affecting Talent Management because it has a high value of loading factor and $n \mathrm{p}$-value already meet the standards. Thus indicators of recruitment and selection, maintaining and developing affect to theTalent Management course at UIN Syarif Hidayatullah.

Personal interest, performance benchmarks and personal target and Personal Improvement actions are all indicators that capable of affecting the Personal Balanced Scorecard because it has a high value of loading factor and $\mathrm{n} p$ value already meet the standards. Thus the Personal Goals indicators, benchmarks and performance targets and measures Personal Improvement effect on The Personal Balanced Scorecard course at UIN Syarif Hidayatullah. 
The Organizational Balanced Scorecard dimension with indicators i.e. the objective of organization, performance benchmarks and targets of the organization, improvement actions are all indicators able to influence the Organizational Balanced Scorecard because it has a high value of loading factor and $\mathrm{n}$ p-value already meet the standards. Thus $\mathrm{t}$ Objective indicators of the organization, performance benchmarks and targets of the organization, improvement actions influence on the Organizational Balanced Scorecard course at UIN Syarif Hidayatullah.

Total Quality Management dimension with indicators that focus on the customer, continuous improvement, management commitment, employee training, comparison of performance are all indicators capable of affecting the Total Quality Management because it has a high value of loading factor and $\mathrm{n} p$-value already meet the standards. Thus indicators focus on customers, continuous improvement, management commitment, employee pelatihan. pemberdayaan, comparison of the performance of an effect on Total Quality Management course at UIN Syarif Hidayatullah.

Competence Management dimension with Acquisition indicator of competence, Competency development and deployment competencies Competency Acquisition Indicators on the first orders have not been able to influence Competence Management because it has a low loading factor value and $n$ p-value that does not meet the standards. The acquisition of competence and thus the first order does not affect the Competence Management course at UIN Syarif Hidayatullah. Meanwhile, other indicators such as the development and deployment Competency are able to influence Competence Management because it has a high value of loading factor and $\mathrm{n} p$-value already meet the standards. Thus indicators of Development and Deployment Competence of human capital affected to a course at UIN Syarif Hidayatullah.

Information in figure 3shows the influence coefficient Champion Total Human Resources Management(Human Resource Management Strategy, Management Firm Infrastructure, management and Contribution Employee, Management of Transformation and Change, Spiritual Promotion Management, Talent Management)of the Total Performance Scorecard(The Personal Balanced 
The Total Performance Scorecard at UIN Syarif Hidayatullah Jakarta

Suhendra

Scorecard, The Organizational Balanced Scorecard, Total Quality Management, Competence Management) Syarif Hidayatullah Jakarta.

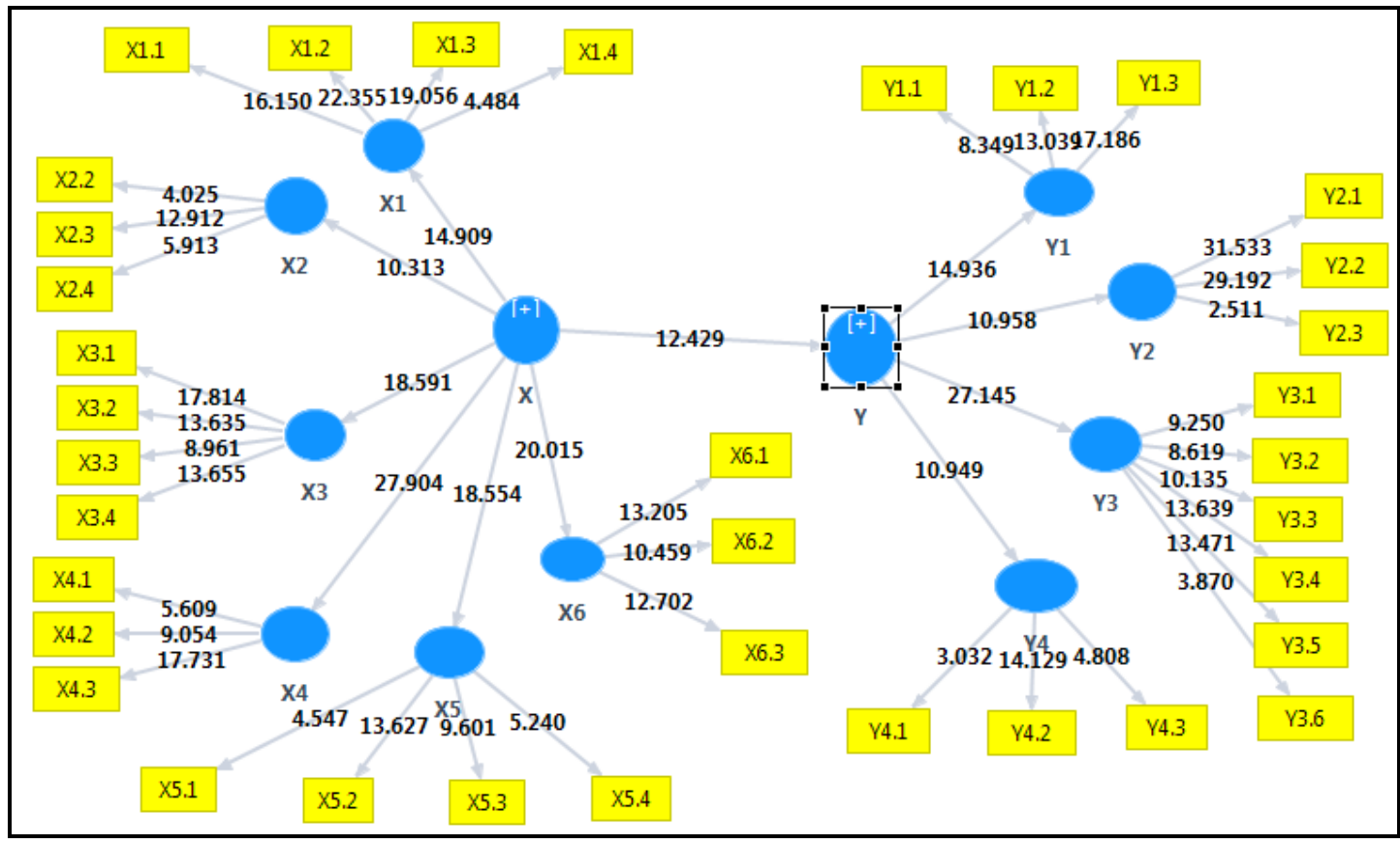

Figure 3. Estimation Result

In the first order for the latent variables Total Human Resources Management Champion in table 3 that a large coefficient of Management Strategic Human Resources to Total Human Resources Management Champion of 0.838 and p-value of 0.000 below 0.05 thereby Strategic Management Human Resources significantly affect the Total Human Resources Management Champion UIN Syarif Hidayatullah Jakarta. Strategic Management of Human Resources influence is positive so that the Management of Strategic Human Resources UIN able to provide a positive impact for Total Human Resources Management Champion UIN Syarif Hidayatullah. Large coefficient of Management Firm Infrastructure to Total Human Resources Management Champion of 0.716 and p-value of 0.000 below 0.05 thereby Infrastructure Management Firm significantly affect the Total Human Resources Management Champion UIN Syarif Hidayatullah Jakarta.The Infrastructure Management Firm influence positive so UIN Infrastructure Management Firm is able to provide a positive impact for Total Human Resources Management Champion UIN Syarif Hidayatullah. Management Employee Contribution coefficients to the Total Human Resources Management Champion of 0.899 and p-value of 0.000 below 0.05 thereby Management Employee 
Contribution significantly affect the Total Human Resources Management Champion UIN Syarif Hidayatullah Jakarta. The effect of the Contribution Employee Management is positive so UIN is able to provide a positive impact for Total Human Resources Management Champion UIN Syarif Hidayatullah.

Management Transformation coefficient and changing to the Total Human Resources Management Champion is 0.905 and p-value of 0.000 below 0.05 thereby Management Transformation and change significantly influences Total Human Resources Champion Management UIN Syarif Hidayatullah Jakarta, Management Transformation influence and change is positive so the Management Transformation and change the UIN is able to provide a positive impact for Total Human Resources Champion Management UIN Syarif Hidayatullah. Promotion Spiritual Management coefficient of the Total Human Resources Champion Management is 0.884 and p-value of 0.000 below 0.05 thereby Spiritual Management Promotions influence significantly on the Total Human Resources Champion Management UIN Syarif Hidayatullah Jakarta. The influence of the Spiritual Management Promotion The positive so the Spiritual Management Promotion UIN is able to provide a positive impact for Total Human Resources Management Champion UIN Syarif Hidayatullah.

Total Talent Management Human Resources Champion Management coefficient is 0.866 and p-value of 0.000 under Talent Management 0.05 thus significantly affect to the Total Human Resources Champion Management UIN Syarif Hidayatullah Jakarta.The effect of Talent Management is positive soTalent Management UIN is able to provide a positive impact for the Total Human Resources Champion Management UIN Syarif Hidayatullah.

In the first order for the Total Performance Scorecard latent variable shows that The Personal Balanced Scorecard coefficient to the Total Performance Scorecard at 0.819 and p-value of 0.000 below 0.05 thus The Personal Balanced Scorecard significant influence of the Total Performance Scorecard UIN Syarif Hidayatullah Jakarta. The Personal Balanced Scorecard influence is positive that The Personal Balanced Scorecard UIN able to positively impact the Total Performance Scorecard UIN Syarif Hidayatullah. Large coefficient The Organizational Balanced Scorecard to Total Performance Scorecard at 0.837 and p- 
The Total Performance Scorecard at UIN Syarif Hidayatullah Jakarta Suhendra

value of 0.000 under 0.05 The Organizational Balanced Scorecard thus significantly affect the Total Performance Scorecard UIN Syarif Hidayatullah Jakarta.

The Organizational Balanced Scorecard has a positive effect so that the Organizational Balanced Scorecard UIN is able to positively impact the Total Performance Scorecard UIN Syarif Hidayatullah. Total Quality Management coefficient is 0.922 and p-value of 0.000 under 0.05 thus Total Quality Management significantly affect to the Total Performance Scorecard UIN Syarif Hidayatullah Jakarta. The effect of Total Quality Management is positive so that Total Quality Management UIN is able to positively impact the Total Performance Scorecard UIN Syarif Hidayatullah. Competence Management coefficient to Total Performance Scorecard is 0.905 and p-value of 0.000 under 0.05 thus Competence Management significantly affect the Total Performance Scorecard UIN Syarif Hidayatullah Jakarta. The positive influence of Competence Management UIN is able to provide a positive impact for the Total Performance Scorecard UIN Syarif Hidayatullah.

In the second

order, Total Human Resources Champion Management coefficient influences the Total Performance Scorecard at 0.823 and p-value of 0.00 under 0.05 thus Total Human Resources Champion Management significantly affect the Total Performance Scorecard UIN Syarif Hidayatullah Jakarta so the Total Human Resources Management Champion UIN is able to provide a positive impact to the Total Performance Scorecard UIN Syarif Hidayatullah.

Here is presented a structural equation model of the effect of Total Human Resources Champion Management to Total Performance Scorecard.

\section{$\mathrm{Y}=\mathbf{0 . 8 2 3} \mathrm{X}_{\mathbf{1}}$}

Based on the structural equation model was obtained that Total Human Resources Management Championhas a positive effect on the Total Performance Scorecard course at UIN Syarif Hidayatullah. Thus the Total Human Resources Management Champion is able to increase the Total Performance Scorecard course at UIN Syarif Hidayatullah Jakarta if it is done a significant improvement on the Total Human Resources Champion Management variable.

Rafat, et.al (2012) shows that there is a significant correlations between the service qualities and human resources, and strategic partner role in human 
resources management. Long and Ismail (2008) shows that role of employee champion and strategic partner contributes most to firm performance. Thill, et.al (2014) shows that the HR role model of Ulrich reflects the HR activities in the DACH region.

\section{CONCLUSION}

This research is going to analyze the relationship between total human resources champions management to the total performance scorecard. The result shows that all dimensions of total human resources champion management such as: human resources strategic management, infrastructure management firm, management employee contribution, management of transformation and changes, spiritual and campaign management, and talent management affect to total human resource management. Besides that, the total human resources management has a significant effect on total performance scorecard.These results imply that the institution should always to improve the all dimension of total human resources champion management.

\section{REFERENCES}

Margetson, D. (1994). Current Educational Reform and the Significance of Problem Based Learning. Occasional Papers. Publication No. 1. Queensland: Griffith University.

Harvey L. \&D. Green. (1993). Defining quality. Assessment and Evaluation in Higher Education, Vol.18: 8-35.

Long, C.S. \& W.K.W. Ismail. (2008). The Vital Roles of Human Resource Professional: A Study on The Manufacturing Companies in Malaysia. The Journal of International Management Studies. Vol. 3 (2): 114-125.

Mukkelli, V. (2015). The Changing Role of Human Resource Management in Twenty First Century Challenges and Opportunities. International Journal of Management Research and Review. Vol. 5 (3): 170-178.

Rafat, M. et.al. (2012). Analysis of the Human Resource Management Role in Hospitals Using Ulrich Model. African Journal of Business Management. Vol. 6 (5): 11943-11952. 
The Total Performance Scorecard at UIN Syarif Hidayatullah Jakarta

Suhendra

Rampersad, H. K. (2003). Total performance scorecard: Redefining management to achieve performance with integrity. Boston: Butterworth Heinemann Business Books.

Thill, K. et. al (2014). HR Roles and Activites. Empirical Result from The DACH Region and Implications for a Future Development of the HR Profession. International Journal of Business and Management. Vol. II (4): 97-109.

Ulrich, D.(1997). Human Resource Champions. USA: Harvard Business School Press. 